\title{
Workshop Pelatihan Video Pembelajaran Menggunakan Aplikasi Open Broadcast Software (OBS) Studio bagi Guru-Guru SMA/SMK di Wilayah Tangerang Raya
}

\section{Imam Sonhaji*1, Ika Endrawijaya², Suse Lamtiar³, Khorul Anam}

\author{
1,2,3,4 Politeknik Penerbangan Indonesia Curug, Indonesia \\ *e-mail: imamsonhaji@gmail.com ${ }^{1}{ }^{\text {Ikaendrawijaya@ppicurug.ac.id }}{ }^{2}$ suse.lamtiar@ppicurug.ac.id ${ }^{3}$, \\ khoirul.anam@ppicurug.ac.id ${ }^{4}$
}

\begin{abstract}
Abstrak
Pandemic COVID-19 menuntut transformasi teknologi pada dunia Pendidikan menjadi sangat cepat karena pembelajaran secara daring / online menjadi pilihan alternatif utama, permasalahan yang dihadapi saat ini adalah tidak semua guru, pengajar atupun dosen memiliki kompetensi dalam membuat media pembelajaran online yang comprehensive dan menarik, sehingga pembelajaran menjadi monoton dan kurang menarik. Melalui kegiatan pengabdian masyarakat ini memberikan worshop pembuatan Video Pembelajaran menggunakan OBS Studio, kegiatan ini bertujuan untuk menambah bekal kemampuan kepada para guru SMK/SMA, pengajar, dan dosen perguruan tinggi dalam pembuatan video pembelajaran. Metode pelaksanaan yang digunaan adalah ceramah, praktik dan diskusi. Hasil kegiatan ini para peserta sejumlah 40 orang memiliki kemampuan dalam membuat video pembelajaran yang variative, interaktif dan bermanfaat dalam pembelajaran daring/online.
\end{abstract}

Kata kunci: Guru, OBS Studio, Pengajar, Video Pembelajaran

\begin{abstract}
The COVID-19 pandemic demands the transformation of technology in the education world to be very fast because online learning is the best choice, but the problem is that not all teachers or lecturers do not have competence in making a comprehensive and attractive online learning media therefore the learning process becomes monotonous and less interesting. Through this community service activity, providing workshop Creating a Learning Videos using OBS Studio, this activity aims to increase skills for vocational/high school teachers, lecturers, and university lecturers in making learning videos. The implementation method used is lecture, practice, and discussion. The results of this activity are 40 participants who can make varied, interactive, and useful learning videos in online learning.
\end{abstract}

Keywords: Learning Videos, Lecturers, OBS Studio, Teachers

\section{PENDAHULUAN}

Sudah lebih dari 2 (dua) tahun pandemi corona virus disease (COVID-19) yang sangat mematikan melanda di seluruh dunia termasuk di Indonesia. Berbagai upaya telah dilakukan untuk memutus mata rantai pandemi COVID-19 agar masa pandemic dapat segera berakhir. Kondisi ini merambah ke dunia Pendidikan, salah satu kebijakan pemerintah yaitu meliburkan aktifitas sekolah dan menghadirkan alternatif dalam proses Pendidikan yakni dengan model pembelajaran daring (Anugrahana, 2020). Surat Edaran Nomor 4 Tahun 2020 tentang Pelaksanaan Kebijakan Pendidikan Dalam Masa Darurat Penyebaran Coronavirus Disease (COVID-19) oleh Menteri Pendidikan dan Kebudayaan Nadiem Makarim pada tanggal 24 Maret 2020. Prinsip yang diterapkan dalam kebijakan masa pandemi COVID-19 adalah "kesehatan dan keselamatan peserta didik, pendidik, tenaga kependidikan, keluarga, dan masyarakat merupakan prioritas utama dalam menetapkan kebijakan pembelajaran" (Makarim, 2020).

Berbagai upaya dilakukan oleh pemerintah, antara lain membuat peraturan untuk mencegah atau mengendalikan laju penyebaran virus COVID-19, pemerintah telah memberlakukan sistem Pembelajaran Jarak Jauh (PJJ) atau yang disebut juga dengan pembelajaran daring (online). Tidak dapat dipungkiri bahwa sistem berbasis teknologi ini tentunya menuntut institusi pendidikan, para pendidik, anak-anak didik dan bahkan orang tua untuk melek teknologi. Dampak positif dari kondisi pandemic dapat memicu percepatan 
transformasi teknologi pendidikan, tentunya pemanfaatan teknologi dalam dunia pendidikan sejalan dengan era revolusi industri 4.0 yang terus berkembang.

Kondisi pandemic ini juga menuntut perubahan paradigma yang cepat dalam pembelajaran yakni orientasi kelas tatap muka atau luring bergeser ke kelas daring sehigga ketergantungan kepada teknologi menjadi sangat besar, Faktor penentu keberhasilan hasil belajar terletak pada bagaimana siswa membangun efikasi diri sehingga keyakinan tersebut yang dijadikan landasan motivasi siswa dalam mengatasi hambatan saat belajar. Selain itu branding sekolah juga menjadi nilai tawar tersendiri dimana teknologi multimedia dalam pembelajaran hanya menjadi pendukung dalam proses pembelajaran(Rumaksari, 2021). Akselerasi transformasi teknologi pendidikan akibat pandemi COVID-19 telah melahirkan berbagai platform program pembelajaran online untuk mendukung tercapainya tujuan pembelajaran yang lebih efektif dan efisien. Aplikasi pembelajaran online dari waktu ke waktu semakin dikembangkan dengan menyediakan fitur-fitur yang memudahkan pemakainya, seperti: zoom meeting, google meet dan lain sebagainya.

Solusi Pengembangan multimedia menjadi pilihan yang paling optimal dengan disusun melalui tahpan yang jelas dan terstruktur yakni pertama tahapan concept, kedua tahapan design, ketiga tahapan material collecting, keempat tahapan assembly, kelima tahapan testing, dan keenam tahapan distribution, salah satunya dengan membuat multimedia melalui video pembelajaran yang bertujuan memberikan contoh nyata kehidupan sehari-hari (Irfan Adi Nugroho, (Universitas Negeri Yogyakarta.) Herman Dwi Surjono, 2019). Pengembangan multimedia untuk peningkatan kualitas pembelajaran saat ini cukup besar peluangnya, karena banyak sisi yang bisa dikembangkan menjadi bahan belajar, ataupun sumber belajar.

Untuk mempertahankan fokus dan perhatian siswa selama melaksanakan pembelajaran multimedia secara online perlu diperhatikan beberapa faktor yang berkonstribusi dekat yakni persepsi manfaat positif bagi para siswa, kemudahan multimedia yang siswa rasakan, dan pengalaman yang dirasakan dengan multimedia (Hariguna \& Akmal, 2019). Keberhasilan penyampaian pesan pembelajaran melalui multimedia salah satunya salah melalui video tergantung pada kosentrasi siswa dan juga daya tarik medianya.

Proses pembelajaran konvensional masih dirasa sangat efektif karena penyampaian secara langsung secara visual, verbal dan ekpresi wajah sangat memberikan kontribusi terbesar dalam proses pembelajaran, namun melalui multimedia atau mobile learning memberikan pengalaman tersendiri seperti pembelajaran tidak lagi dibatasi waktu dan tempat, seamangat lebih tinggi melalui multimedia yang baik, formalitas pembelajaran menjadi lebih rileks, proses belajar mandiri maupun kolaboratif tetap berjalan, focus siswa menjadi lebih lama dan dapat menumbuhkan rasa percaya diri yang cukup tinggi (Hidayat \& Gayuh Utomo, 2014).

Pengunaan video dalam pembuatan multimedia dapat membantu siswa menguatkan mental belajarnya sehingga apa yang didengar dan dilihat dari suara, gambar atau simbol dapat terima dengan baik selama aktitas belajar tersebut berlangsung.(Abidin \& Abu, 2021). Untuk itu kemampuan dalam membuat multimedia video pembelajaran menjadi hal sangat dibutuhkan pada kondisi saat ini.

Dalam beberapa penelitian menunjukan bahwa hasil pembelajaran sangat tinggi apabila melibatkan indra penglihatan (visual), indra pendengaran (audio) serta pengalaman dari apa yang dilihat (Elpira \& Ghufron, 2015). Berdasarkan hal tersebut dalam pembuatan video pembelajaran haruslah didukung dengan kualitas gambar dan audio yang baik serta keterlibatan siswa untuk mempraktekannya.

Politeknik Penerbangan Indonesia Curug (PPI Curug) yang merupakan salah satu lembaga pendidikan vokasi di Indonesia di bawah Kementerian Perhubungan turut berperan aktif dalam menekan laju penyebaran virus COVID-19 dengan mematuhi protocol kesehatan dalam melaksanakan kebiasaan normal baru (new normal) oleh seluruh civitas akademika. Tidak hanya berhenti di situ saja, melalui kegiatan Pengabdian Kepada Masyarakat (PKM) sebagai salah satu Tridharma Perguruan Tinggi, dosen PPI Curug ikut andil dalam percepatan transformasi teknologi pendidikan kepada masyarakat, yaitu antara lain dengan melaksanakan kegiatan Pengabdian Kepada Masyarakat, memberikan pelatihan pembuatan materi video pembelajaran menggunakan aplikasi Open Broadcast Software (OBS) Studio guna penambahan 
pengetahuan, wawasan dan keterampilan bagi guru-guru SMP dan SMA/SMK) di wilayah Tangerang Raya.

Permasalahan yang dihadapi mitra (dalam hal ini adalah para guru) tergambar dalam pelaksanaan pembelajaran daring selama pandemi COVID-19, masih banyak kendala yang dihadapi. Adapun kendala yang dihadapi oleh para guru dalam pembelajaran daring seringkali media pembelajaran yang digunakan oleh para guru dominan monoton, tidak variatif, tidak menarik dan tidak interaktif sehingga membuat anak-anak didik merasa jenuh/bosan. Hal ini dikarenakan para guru belum begitu memahami media pembelajaran apa saja yang bisa digunakan dalam menyiapkan materi ajar daring. Kondisi ini tentu akan sangat berdampak pada bagaimana melaksanakan pembelajaran onling (daring) secara efektif dan efisien, sehingga penyerapan materi pelajaran dapat tercapai optimal. Maka untuk mengatasi kendala tersebut, antara lain perlu diberikan pelatihan pembuatan media pembelajaran daring bagi para guru, pengajar, ataupun dosen.

\section{METODE}

Kegiatan Pengabdian Kepada Masyarakat (PKM) dosen PPI Curug dalam bentuk pelatihan pembuatan materi video pembelajaran menggunakan aplikasi Open Broadcast Software (OBS) Studio bagi guru-guru SMP dan SMA/SMK di wilayah Tangerang Raya akan dilaksanakan secara online (daring) melalui zoom meeting.

Adapun tahapan-tahapan kegiatan PKM ini adalah sebagai berikut:

\subsection{Tahap Persiapan}

Pada tahap persiapan kegiatan pengabdian masyarakat ini dilakukan beberapa kegiatan yakni sebagai berikut:

a. Penyusunan proposal kegiatan pengabdian masyarakat sebagai dokumen awal.

b. Penyusunan flyer sebagai alat promosi penjaringan peserta kegiatan pengabdian masyarakat.

c. Penyiapan kelengkapan administrasi dan lain-lain.

d. Penyiapan peralatan praktek seperti laptop, aplikasi OBS, kamera, green screen, microphone, dan lain-lain.

e. Menyiapakan link pendaftaran peserta, link absensi kegiatan serta link evaluasi kegiatan.

\subsection{Tahap Pelaksanaan}

Pada tahap pelaksanaan kegiatan pengabdian masyarakat ini dilakukan beberapa kegiatan yakni sebagai berikut:

a. Pelatihan dilaksanakan pada 21-22 Nopember 2021 selama 2 (dua) hari.

b. Hari pertama pembukaan oleh pejabat PPI Curug pada pukul 08.00-09.00 Wib, dilanjutkan dengan penjelasan kepada peserta tentang tata tertib pelaksanaan kegiatan pelatihan.

c. Kegiatan workshop pelatihan mulai jam 09.00 sampai dengan 16.00 wib setiap harinya.

d. Hari kedua pembekalan materi pengenalan aplikasi Open Broadcast Software (OBS) studio (rekam layer), diakhiri dengan memberikan tugas mandiri kepada peserta untuk membuat video pembelajaran dan dikumpulkan 1 (satu) minggu kemudian.

e. Pada akhir sesi diberikan link evaluasi kegiatan untuk melihat respon para peserta pelatihan.

f. kegiatan pengabdian masyarkat resmi ditutup oleh pejabat yang berwenang tanggal 23 Nopember 2021 Pukul 16.00 WIB.

\subsection{Tahap Pelaporan}

Pada tahap pelaporan kegiatan pengabdian masyarakat ini dilakukan beberapa kegiatan yakni sebagai berikut:

a. Pengumpulan hasil pembuatan video pembelajaran dari para peserta workshop.

b. penyusunan laporan akhir kegiatan pengabdian masyarakat. 


\section{HASIL DAN PEMBAHASAN}

Pembelajaran daring menuntut seluruh Lembaga Pendidikan bersiap dalam berbagai hal baik sarana maupun prasarana serta bahan ajar yang sudah harus mengadaptasi tuntutan video pembelajran online yang menarik dengan memanfaatkan teknologi Pendidikan ataupun media sosial (Herwanto \& Hatmo, 2020). Untuk itu, Pengabdian kepada masyarakat adalah usaha untuk menyebarluaskan ilmu pengetahuan, teknologi, dan seni kepada masyarakat. Kegiatan tersebut harus mampu memberikan suatu nilai tambah bagi masyarakat, baik dalam kegiatan ekonomi, kebijakan, dan perubahan perilaku (sosial).

Kegiatan Pengabdian Kepada Masyarakat (PKM) ini adalah kegiatan workshop pelatihan pembuatan media belajar dengan menggunakan OBS Studio untuk para pengajar baik dari SMA, SMK, maupun perguruan tinggi sehingga dapat meningkatkan kualitas pengajaraanya dan meningkatkan minat belajar siswa melalui media video pembelajaran yang menarik. Kegiatan tersebut terdiri dari 2 (dua) sesi yakni sesi 1 (satu) adalah knowledge sharing and discussion sedangakan sesi 2 (dua) adalah pendampingan pembuatan bahan ajar daring.

Kegiatan ini mendapatkan antusias yang cukup tinggi dari para peserta pelaihan mengingat pembelajaran daring menjadi sangat popular saat ini, sehingga diharapkan gairah para murid atau mahasiswa tetap semangat dalam pembelajaran daring tersebut. Kegiatan PKM ini dilaksanakan secara daring dengan memanfaatkan Zoom Meeting mengingat kondisi pandemi yang masih berlangsung sehingga ketergantungan jaringan internet menjadi sangat besar baik para peserta pelatihan maupun pemateri pelatihan.

Kegiatan Pengabdian Kepada Masyarakat (PKM) dapat menjangkau wilayah yang lebih luas dengan media daring zoom meeting dari yang awalnya ditargetkan wilayah Tangerang raya tetapi pada hasil akhir beberapa peserta berasal dari luar seperti Surabaya, Kalimantan, Aceh, dan lain sebagainya.

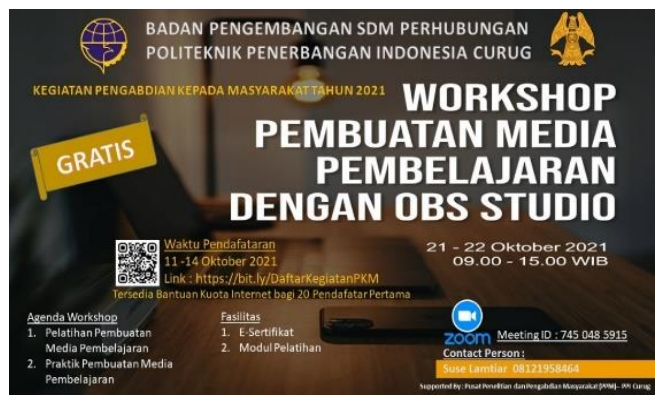

Gambar 1. Flyer Workshop

Gambar 1 merupakan flyer pengumuman sebagai promosi kepada masyarakat yang akan disasar, penyebaran flyer tersebut dapat melalui social media PPI curug, Group Whatapp, dan media lainnya. berikut:

Untuk materi workshop yang dilaksanakan pada kegiatan PKM ini adakah sebagai

1. Pengenalan tentang OBS

Pada sesi ini dijelaskan secara singkat kepada peserta workshop tentang Aplikasi OBS Studio kegunaannya dalam pembuatan media pembelajaran dan keunggulannya dibamdimgkan dengan aplikasi-aplikasi lain yang sejenis.

2. Download dan instalasi OBS Studio

Menjelaskan bagaimana cara mengunduh aplikasi OBS studio sesuai dengan Operating System pada perangkat komputer serta langkah-langkah dalam instalasi program.

3. Pemahaman scene dan source

Memberikan pemahaman kepada peserta tentang Scene dan Source, menjelaskan macammacam source dan fungsinya serta mengatur properti dari masing-masing source.

4. Desain tampilan OBS

5. Merekam layar dengan OBS

6. Upload Video ke Youtube 
7. Video Streaming nenggunakan OBS pada:
a. Youtube
b. Facebook
c. Youtube dan Facebook secara bersamaan
Peserta kegiatan PKM ini dengan data sebagai berikut:

Tabel 1. Peserta Kegiatan PKM

\begin{tabular}{|c|c|c|}
\hline Nama Peserta & Profesi & Sekolah/ Perguruan Tinggi \\
\hline ASEP KURNIAWAN & Guru & SDN Nalagati \\
\hline Nawang Kalbuana & Dosen & Politeknik Penerbangan Indonesia Curug \\
\hline Nanik Triwahyuni, ST & Guru & SMK Penerbangan Dharma Wirawan \\
\hline AKHMAD KURNIA..S.Pd. MM & Guru & SMAN 15 KAB TANGERANG \\
\hline Suyanto & Guru & SMK Penerbangan Aero Dirgantara \\
\hline Anggraeni Trisna Dewi. S.pd & Guru & SMA YUPPENTEK 3 LEGOK \\
\hline Risma Gembiraria Butarbutar & Guru & SMK Negeri 3 Kota Tangerang Selatan \\
\hline Ika Sartika, S. AP & Guru & SMK NEGERI 3 KOTA TANGERANG \\
\hline ade Agus Priyanka & Guru & UPTD Latihan Kerja Kabupaten Tangerang \\
\hline Lidya Fery S. Pd. K & Guru & SMKN 3 Tangsel \\
\hline Radian paprika & Guru & Smkn1 Kragilan \\
\hline Wawan Hendrawan & Guru & SMAN 29 Kab. Tangerang \\
\hline Andi Permana & Guru & SMKN 1 KAB. TANGERANG \\
\hline Sumiyati, S.Pd & Guru & SMKN 3 Kota Tangerang Selatan. \\
\hline Giyanti & Guru & Universitas Serang Raya \\
\hline Ebby Gunawan & Guru & SMKN 1 Kab. Tangerang \\
\hline Dra. Mulyati & Guru & SMKN 3 Kota Tangerang Selatan \\
\hline Deni Dwi Andrian & Guru & SMKN 3 Kota Tangerang Selatan \\
\hline Elfi Amir, SSiT, SE, MM & Dosen & PPI Curug \\
\hline Ebby Gunawan & Guru & SMKN 1 Kab. Tangerang \\
\hline MOCHAMAD KURNIYANTO & Guru & SMK Penerbangan Kartika Aqasa Bhakti Semarang \\
\hline Ottih Sugiroh, S. Sos & Guru & SMKN 1 Kab Tangerang \\
\hline Hafizh Afkar Makmur & Dosen & ITB \\
\hline Andi Rachmanto,S.Pd & Guru & SMKN 3 Tangerang Selatan \\
\hline RINI SADIATMI & Dosen & PPIC \\
\hline Surya Wedi & Guru & SMKN 3 Kota Tangerang Selatan \\
\hline Nurmalia Yunita, S.Pd & Guru & SMKN 3 Tangerang Selatan \\
\hline Muhammad Arief Rifa'i & Guru & SMKN 3 Kota Tangerang Selatan \\
\hline Irma Sunyani & Guru & SMKP DIRGHANTARA \\
\hline Saleh Ibrahim & Guru & SMK Muhammadiyah 2 Salam Magelang \\
\hline ROBIANSYAH & Guru & SMKN 1 Kab Tangerang \\
\hline Chairul Amri S.Pd & Guru & SMA Muhammadiyah 1 \\
\hline Chairul Amri S.Pd & Guru & SMA MUHAMMADIYAH 1 \\
\hline ENDANG SUGIH ARTI & Dosen & PPIC \\
\hline Ida Apriyanti & Guru & SMKN 1 kab Tangerang \\
\hline Roheman, M.Pd & Guru & SMKN 3 Tangerang Selatan \\
\hline Yuniaty Puspita, S.SiT & Guru & SMK Penerbangan Aero Dirgantara \\
\hline Nunung Fatmawati, S.T., M.T. & Dosen & $\begin{array}{l}\text { Poltek Gajah Tunggal dan Universitas } \\
\text { Muhamadiyah Banten }\end{array}$ \\
\hline Suhernih & Guru & SMKN 3 Tangerang Selatan \\
\hline Benny Kurnianto & Dosen & PPI Curug \\
\hline Sulviana Dale & Guru & SMAN 3 Kab Tangerang \\
\hline LOMRI SH & Guru & SMK Penerbangan Dirghantara \\
\hline Adi Wijaya & Guru & SMKN 3 KOTA TANGERANG SELATAN \\
\hline ASJAYADIN & Guru & SMKN 1 Kab. Tangerang \\
\hline
\end{tabular}


Merujuk Tabel 1 diatas, bahwa kegiatan PKM ini dihadiri sejumlah 40 Peserta di dengan memiliki latar belakang yang cukup beragam yakni guru SMA, guru SMK dan Dosen. Pendafataran melalui link pendafataran yang tertera pada flyer kegiatan.

Kegiatan PKM ini dibuka secara resmi oleh Kepala Pusat Penelitian dan Pengabdian Masyarakat PPI Curug yang ditunjukan pada Gambar 2 tanggal 22 Oktober 2021 dengan dihadiri para pemateri dan seluruh peserta PKM.

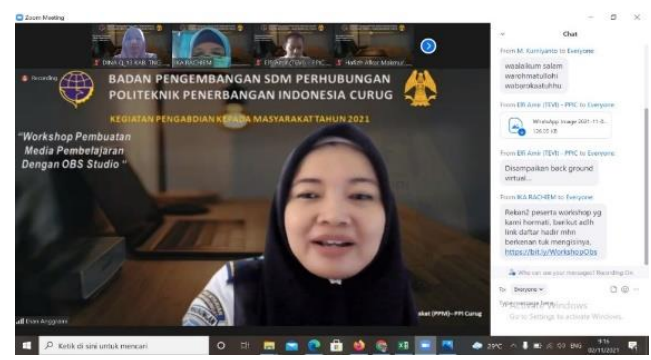

Gambar 2. Pembukaan PKM

Selanjutnya dilaksanakan penyampaian materi kepada seluruh peserta PKM selama 1 hari dan dilanjutkan pendampingan pembuatan materi daring pada hari selanjutnya.

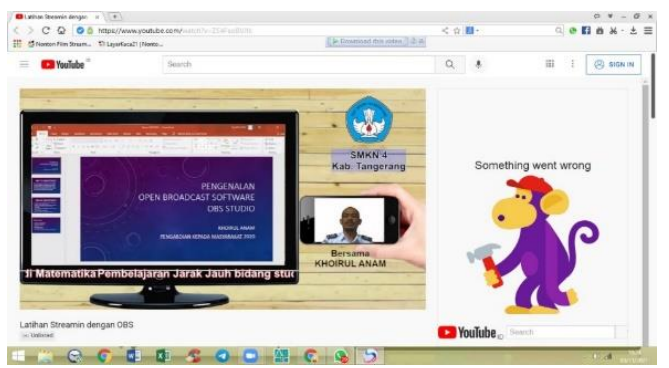

Gambar 3 Penyampain Materi

Gambar 3 merupakan tampilan narasumber dalam penyampaian materi, secara umum hasil dan luaran yang dihasilkan kegiatan ini adalah mencakup 2 hal yaitu penyiapan bahan ajar dan pengayaan bahan ajar.

Penyiapan bahan ajar mencakup bagaimana membuat bahan ajar menjadi bentuk prsetasi yang menarik dalam power pint, sedangkan pengayaan bahan ajar lebih kepada bagaimana membuat bahan ajar, menjadi menarik bagi siswa melalui video. Sehingga pembelajaran tetap berjalan dan siswa dapat mengakses materi kapanpun selama terhubung internet baik melalui youtube mapun facebook. Video pembelajaran tidak hanya berfungsi untuk menyampaikan materi ajar, namun juga dapat memberikan pengalaman baru sehingga minat siswa menjadi meningkat selanjutnya dapat dipraktekkan oleh masing-masing secara mandiri (Demayanti \& Soenarto, 2018).

Pada sesi akhir peserta ditugaskan untuk membuat video pembelajaran dengan menggunakan OBS, sehingga diharapakan peserta dapat mempraktekkan materi yang sudah diberikan selama pelatihan workshop berlangsung. Berikut hasil-hasilnya oleh para peserta sebagai perwakilan peserta kegiatan Pengandian Kepada Masyarakat ini.
1. Nama : Ika Sartika, S.AP
Asal : SMKN 3 kota Tangerang Selatan
Link : https://youtu.be/CAxAq4ATeNk
Materi : Animasi Scenario

Gambar 4 merupakan hasil praktek dari peserta pertama yang diambil dari screenshoot channel youtube yang tertera pada link diatas. Video yang dihasilkan merupakan materi ajar yang digunakan selama pembelajaran tatap muka. 


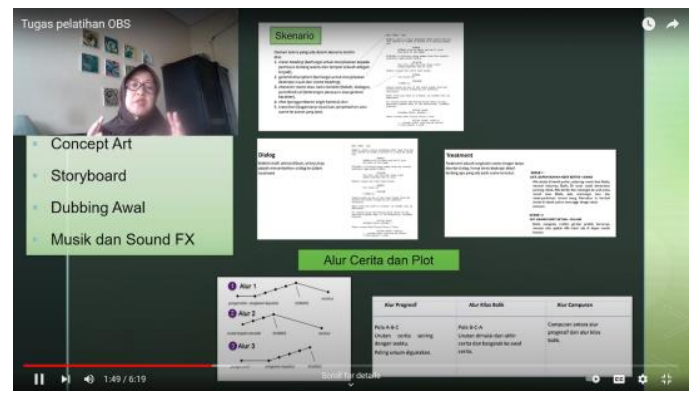

Gambar 4. Peserta 1

2. Nama : Ottih Sugiroh, S, Sos

Asal : : Smkn1 Kab Tangerang

Link : https://youtu.be/Xm1uyfDTWuY

Materi : Tata Tertib Sekolah

Gambar 5 merupakan hasil praktek dari peserta kedua yang diambil dari screenshoot channel youtube yang tertera pada link diatas. Video yang dihasilkan merupakan materi yang disampaikan kepada siswa baru, sehingga siswa baru bisa mengulang-ulang sendiri untuk pemahaman tata tertib di sekolah.

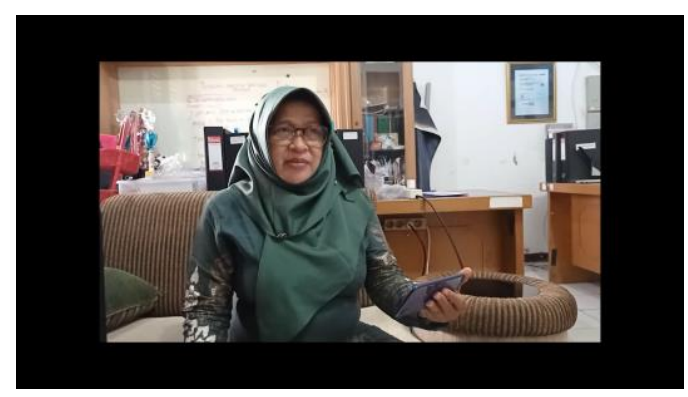

Gambar 5. Peserta 2

3. Nama : Robiansyah, S.T

Asal : SMKN 1 KAB TANGERANG

Link : : https://youtu.be/7XkUorpzsvQ

Materi : Pengenalan Jurusan Teknik Elektronika Industri

Gambar 6 merupakan hasil praktek dari peserta ketiga yang diambil dari screenshoot channel youtube yang tertera pada link diatas, materi pengenalan jurusan Teknik elektronika industri yang biasa disampaikan pada masa pengenalan lingkungan sekolah menjadi lebih menarik.

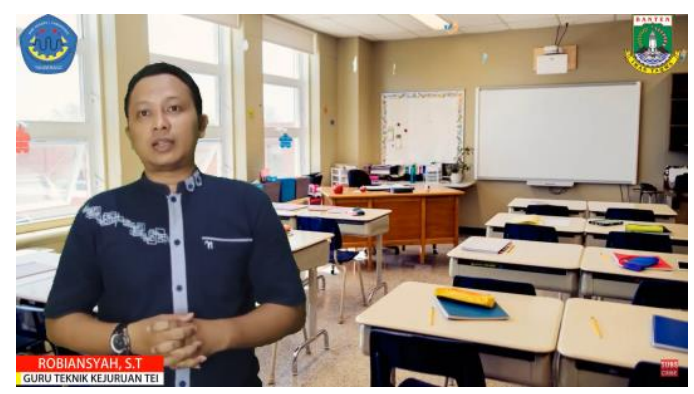

Gambar 6. Peserta 3

4. Nama : Yuniaty Puspita

Asal : :SMK Penerbangan Aero Dirgantara

Link : https://youtu.be/y ZIopb4ax0

Materi : Basic Aircraft Technical Knowledge 
Gambar 7 merupakan hasil praktek dari peserta keempat yang diambil dari screenshoot channel youtube yang tertera pada link diatas, materi Basic Aircraft Teknical Knowledge yang merupakan materi dasar dapat terlaksana dengan baik dan sangat efektif karena siswa dapat mengakses melalui youtube kapanpun dan dimanapun belajarnya.

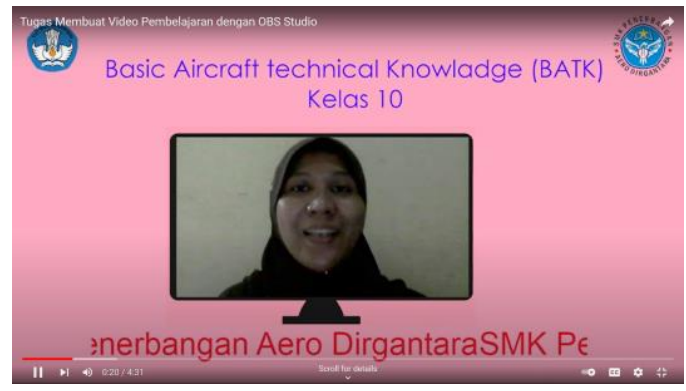

Gambar 7. Peserta 4

5. Nama : Ida Apriyanti, S.Hum

Asal : SMKN 1 KAB TANGERANG

Link : $\quad$ https://youtu.be/0vlkhhPu ak

Materi : Proyek Penguatan Profil Pelajar Pancasila dan Budaya Kerja

Gambar 8 merupakan hasil praktek dari peserta kelima yang diambil dari screenshoot channel youtube yang tertera pada link diatas, materi Pancasila dan budaya kerja menjadi tidak membosankan karena dilengkapi video pembelajaran yang unik dan menarik perhatian.

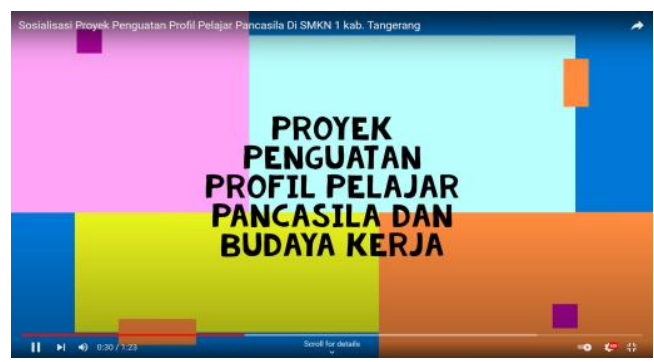

Gambar 8. Peserta 5

6. Nama : Chairul Amri S.Kom

Asal : :SMA Muhammadiyah 1 Tangerang

Link $\quad:$ https://youtu.be/Uf1mbbzu4yU

Materi : Peringatan Hari Pahlawan

Gambar 9 merupakan hasil praktek dari peserta keenam yang diambil dari screenshoot channel youtube yang tertera pada link diatas, peserta dapat mempraktekan pembuatan video pembelajaran dengan baik dan terus menerus berlatih dan berkreasi sehingga menjadi materi yang dapat diterima siswa.

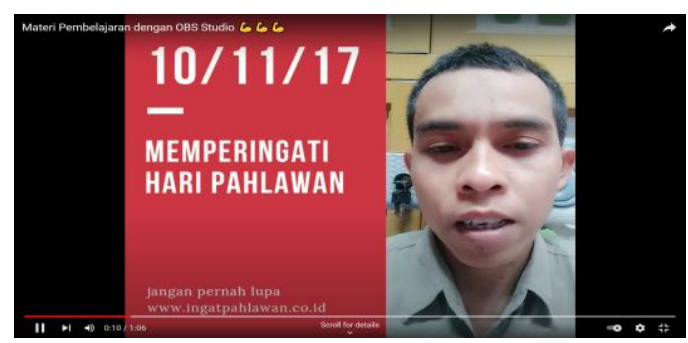

Gambar 9. Peserta 6

Dapat disimpulkan bahwa, kegiatan PKM tersebut mendapat antusias yang tinggi dari 
para peserta workshop sehingga mampu memberikan wawasan, pengetahuan dan keterampilan baru bagi para pengajar baik para guru maupun dosen.

Pada akhir kegiatan PKM ini dilaksanalan evaluasi kegiatan dengan memberikan kuisioner kepada seluruh peserta. Adapun hasilnya adalah sebagai berikut:

Tabel 2. Evaluasi PKM

\begin{tabular}{|c|c|c|c|c|}
\hline \multirow[t]{2}{*}{ Item Evaluasi } & \multicolumn{4}{|c|}{ Skor } \\
\hline & $\begin{array}{l}\text { Sangat } \\
\text { Tidak } \\
\text { Sesuai }\end{array}$ & $\begin{array}{l}\text { Tidak } \\
\text { Sesuai }\end{array}$ & Sesuai & $\begin{array}{l}\text { Sangat } \\
\text { Sesuai }\end{array}$ \\
\hline $\begin{array}{l}\text { Materi PKM sesuai kebutuhan Mitra } \\
\text { Peserta }\end{array}$ & - & - & $44.4 \%$ & $55.56 \%$ \\
\hline $\begin{array}{l}\text { Materi PKM sesuai harapan Mitra/ } \\
\text { Peserta. }\end{array}$ & & & $51.9 \%$ & $48.1 \%$ \\
\hline Penyampaian materi menarik. & - & $3.7 \%$ & $59.3 \%$ & $37 \%$ \\
\hline Materi jelas dan mudah dipahami. & - & $11.1 \%$ & $44.4 \%$ & $44.4 \%$ \\
\hline $\begin{array}{l}\text { Waktu yang tersedia sesuai untuk } \\
\text { penyampaian materi dan kegiatan PKM. }\end{array}$ & - & $18.5 \%$ & $51.9 \%$ & $29.6 \%$ \\
\hline $\begin{array}{l}\text { Mitra / peserta berminat mengikuti } \\
\text { selama sesuai kebutuhan. }\end{array}$ & - & - & $51.9 \%$ & $48.1 \%$ \\
\hline $\begin{array}{l}\text { Anggota PKM memberi pelayanan sesuai } \\
\text { dengan kebutuhan. }\end{array}$ & - & - & $63 \%$ & $37 \%$ \\
\hline $\begin{array}{l}\text { Kegiatan PKM dilakukan secara } \\
\text { berkelanjutan. }\end{array}$ & - & - & $59.3 \%$ & $40.7 \%$ \\
\hline $\begin{array}{l}\text { Setiap pertanyaan/ permasalahan } \\
\text { ditindaklanjuti oleh pemateri atau tim } \\
\text { PKN dengan baik. }\end{array}$ & - & - & $48.1 \%$ & $51.9 \%$ \\
\hline $\begin{array}{l}\text { Peserta atau mitra mendapatkan manfaat } \\
\text { secara langsung dari kegiatan PKM. }\end{array}$ & & $3.7 \%$ & $51.9 \%$ & $44.4 \%$ \\
\hline $\begin{array}{l}\text { Kegiatan PKM berhasil meningkatakan } \\
\text { kecerdasan/pengetahuan/ skill peserta. }\end{array}$ & - & - & $51.9 \%$ & $48.1 \%$ \\
\hline $\begin{array}{l}\text { Secara umum, peserta/mitra puas } \\
\text { dengan kagiatan PKM }\end{array}$ & - & - & $55.6 \%$ & $44.4 \%$ \\
\hline
\end{tabular}

Merujuk Tabel 2 diatas, pada akhir sesi pelatihan diberikan kuisoner secara online menggunakan google form yang disebarkan ke seluruh peserta, kuisioner tersebut berisikan penilaian atau tanggapan terhadap proses penyelenggaraan proses kegiatan pengabdian masyarakat, hasil dari evaluasi penyenggaraan kegiatan Pengbdian Kepada Masyarakat mayoritas memberikan tanggapan yang sesuai dan sangat sesuai dari mulai kualitas materi, kualitas pemateri, kecukupan waktu, pelayanan panitia pada program kegiatan, keberlanjutan program kegiatan, kemanfaatan program kegiatan, dan dampak peningkatan pengetahuan dan kompetensi bagi para peserta, sehingga dapat disimpulkan bahwa para peserta sangat menyambut baik program kegiatan pengabdian kepada masyarkat ini dan mengharapkan program tersebut dapat berjalan secara berkesinambungan.

\section{KESIMPULAN}

Kegiatan Pengabdian Kepada Masyarakat (PKM) dengan judul Pelatihan Pembuatan Materi Video Pembelajaran Menggunakan Aplikasi Open Broadcast Software (OBS) Studio dapat ditarik kesimpulan adalah kegiatan PKM ini disambut dengan baik oleh para peserta dan berjalan baik sesuai rencana, Seluruh peserta mengikuti pelatihan dengan baik dan menghasilkan beberapa video yang diupload melalui link youtube. Hasil evaluasi penyelenggaraan PKM ini dengan tanggapan baik. 


\section{UCAPAN TERIMA KASIH}

Tim Dosen Pengabdian Kepada Masyarakat mengucapkan terima kasih kepada Direktur PPI Curug yang telah memberi dukungan financial terhadap pengabdian ini. Selain itu apresiasi yang setinggi-tingginya kepada para peserta guru SMA, SMK dan Dosen yang mengikuti kegiatan PKM ini sehingga kegaitan ini dapat berjalan sebagaimana mestinya.

\section{DAFTAR PUSTAKA}

Abidin, Z. Z., \& Abu, M. S. (2021). The Improvement of Geometric Thinking Levels of Secondary School Students Using Geometry Learning Video based on Van Hiele Theory. Modern Perspectives in Language, Literature and Education Vol. 9, 2(1), 13-21. https://doi.org/10.9734/bpi/mplle/v9/3633f

Anugrahana, A. (2020). Hambatan, Solusi dan Harapan: Pembelajaran Daring Selama Masa Pandemi COVID-19 Oleh Guru Sekolah Dasar. Scholaria: Jurnal Pendidikan dan Kebudayaan, 10(3), 282-289. https://doi.org/10.24246/j.js.2020.v10.i3.p282-289

Demayanti, F., \& Soenarto, S. (2018). Pengembangan video pembelajaran bumbu dan rempah pada mata pelajaranpengolahan makanan kontinental. Jurnal Inovasi Teknologi Pendidikan, 5(1), 91-102. https://doi.org/10.21831/jitp.v5i1.14028

Elpira, N., \& Ghufron, A. (2015). Pengaruh Penggunaan Media Powerpoint Terhadap Minat Dan Hasil Belajar Ipa Siswa Kelas Iv Sd. Jurnal Inovasi Teknologi Pendidikan, 2(1), 94-104. https://doi.org/10.21831/tp.v2i1.5207

Hariguna, T., \& Akmal, akmal@mpbi uad ac id. (2019). Assessing students' continuance intention in using multimedia online learning. Telkomnika (Telecommunication Computing Electronics and Control), 17(1), 187-193. https://doi.org/10.12928/TELKOMNIKA.v17i1.10328

Herwanto, S., \& Hatmo, D. (2020). Dampak Pandemi COVID-19 Terhadap Efektivitas Pembelajaran Jarak Jauh Secara Daring. Jurnal pendidikan dan kebudayaan, 11(2), 115-122.

Hidayat, A., \& Gayuh Utomo, V. (2014). Open Source Based M-Learning Application for Supporting Distance Learning. TELKOMNIKA (Telecommunication Computing Electronics and Control), 12(3), 657. https://doi.org/10.12928/telkomnika.v12i3.104

Irfan Adi Nugroho, (Universitas Negeri Yogyakarta.) Herman Dwi Surjono, U. N. Y. (2019). PENGEMBANGAN MULTIMEDIA PEMBELAJARAN INTERAKTIF BERBASIS VIDEO MATERI SIKAP CINTA TANAH AIR DAN PEDULI LINGKUNGAN. Jurnal Inovasi Teknologi Pendidikan, PENGEMBANGAN MULTIMEDIA PEMBELAJARAN INTERAKTIF BERBASIS VIDEO MATERI SIKAP CINTA TANAH AIR DAN PEDULI LINGKUNGAN, 6(1), 29-41.

Makarim, N. (2020). No Title. Pelaksanaan Kebijakan Pendidikan Dalam Masa Darurat Penyebaran Coronavirus Disease (COVID-19).

Rumaksari, A. N. (2021). Pembelajaran Daring: Ancaman Perusahaan EdTech Pada Sekolah Ditengah Pandemi COVID-19. Scholaria: Jurnal Pendidikan dan Kebudayaan, 11(1), 30-36. https://doi.org/10.24246/j.js.2021.v11.i1.p30-36 